\title{
The Literacy Test of the Archipelago Region as the Expression of Indonesian Youth's Patriotism
}

\author{
Ketut Prasetyo* \\ Geography Education Department \\ Faculty of Social Sciences and Law, \\ Universitas Negeri Surabaya \\ Surabaya, East Java, Indonesia \\ ketutprasetyo@unesa.ac.id
}

\author{
Sarmini \\ Pancasila and Civic Education \\ Department \\ Faculty of Social Sciences and Law, \\ Universitas Negeri Surabaya \\ Surabaya, East Java, Indonesia \\ sarmini@unesa.ac.id
}

\author{
Kusnul Khotimah \\ Social Science Education Department \\ Faculty of Social Sciences and Law, \\ Universitas Negeri Surabaya \\ Surabaya, East Java, Indonesia \\ kusnulkhotimah@unesa.ac.id
}

Katon Galih Setyawan

Social Science Education Department

Faculty of Social Sciences and Law,

Universitas Negeri Surabaya

Surabaya, East Java, Indonesia

katonsetyawan@unesa.ac.id

\begin{abstract}
In the global era, the young generation is one important component to sustainable developing the country. The modal for to regarding the country is knowing territorial zone. When we are falling the territorial my country is one indicator no loving is my country. The territorial zone of state is one of importing to be knowing for all people. Specially for young generation of one nation knowing about territorial his country is one indicator for loving at his country. Method of researched is choosing by case study at student Geographic Department-sSurabaya State University. Instrument of collecting data by cognitive map. The researched colleting of data by randomize testing of 50 student, by split at 30 male student and 20 female students. The data to be analysis by description-Quantitative method. The object of testing knowing is: 1. name island, 2. name of city, 3. name of mount, and 4. name of ocean is will be indicator for knowing of Indonesia territorial zone. The result of the researched at Student of Geographic Department-State University of Surabaya-Indonesia, about knowing about territorial zone is very low. The rank knowing number one until lower is 1) name of ocean or sea, 2) name of island, 3 ) name of city, last of rank is 4) name of mountain. Finally, the advisor for rushing at result of knowing about territorial zone at program educated must be large and developing the educated program, especially at how to know territorial Indonesia is my country.
\end{abstract}

Keywords: literacy test, Archipelagic Region, youth patriotism

\section{INTRODUCTION}

In order to commemorate /commemorate the Youth Oath on October 28, 1928, we are intrigued by the question "are we still one between us in nationalism and language?" Indonesia, our homeland must be maintained in a single environment ika. Quoting [1] opinion who expressed concern about the lack of nationalism as follows: "The future of the Indonesian nation is threatened with gloom due to a low sense of nationalism among the youth. More and more years, the momentum of the Youth Oath commemoration which became the beginning of the birth of nationalism among young people was increasingly ignored. Only a few young people care, even those that are more ceremonial."

Margaret thatcher as a prime minister of England never sucked the patriotism of young generation. This condition is caused that when the England youth was quested what are the mother of the city? They can't answer all right. Then followed by the question, Where Is the City Mom? The Little A Literally May Be Answer Correct.

The indicator does not recognize the national capital, is one indicator of reduced nationalism or patriotism. This condition is very dangerous for the younger generation, because it is feared that if the youth do not know the capital of their country, then if the capital is empowered or taken over by another country, then the young man will not know. Thus, it is feared that the declining literacy of the phenomenon of the name of the national capital, the location of the capital city and national borders also makes an indicator of a sense of patriotism of a nation.

The territory of the Unitary Republic of Indonesia which is located around the equator, and between the continents of Australia and Asia, and located between the Indian and Pacific Oceans, seems not to be memorized, but it is necessary to know the position in the archipelago.

National borders in the current era of globalization seem to still be needed both physically and securely. Indonesia which has an area which is divided by islands of approximately seventeen thousand islands, always needs 
attention to remain united in the territory of the Unitary Republic of Indonesia.

The Indonesian independence fighters who have promoted Indonesia are increasingly diminishing and are increasingly depleted. Therefore, it seems that the younger generation is the main foundation for maintaining the Unitary State of the Republic of Indonesia [2].

The young generation that is expected to be the unifying successor of the Unitary State of the Republic of Indonesia is expected not to neglect that we are united and intact from Sabang until Merauke. We are inseparable from the Sea, Strait, Mountains and Rivers. Our region is a unit of land and sea from Sabang until Merauke.

The Indonesian territory which is relatively broad, consisting of islands, and geographical conditions scattered by each island, is a challenge for us to love the archipelago. The length of the territory of Indonesia is almost the same length as the European countries to the west end of the mainland of Asia, becoming its own obstacle in uniting the archipelago.

Archipelago in Indonesia, amounting to approximately 17 thousand, spread from Sabang to Merauke. In connection with the large amount, some have been occupied, but some have not. inhabited Some 17 thousand of these islands have been named, but some have not yet been named. This is the challenge to continue to love the archipelago.

In addition, the State of Indonesia directly borders with neighboring countries. Among those bordering on neighboring countries in the form of land, namely bordering Malaysia, Brunei Darussalam, Papua New genie, and Timor Leste. As for the neighboring countries bordering the waters, namely: Philippines. Australia and Singapore.

If we are negligent or do not know the territory of our country, this indicates that we do not have patriotism. So that colonialism or the struggle for Indonesian territory by other countries has never been felt by us. The Ambalat island case, the Sepadan- Ligitan island case should be a meaningful lesson for us in the unitary state of the Republic of Indonesia. The Soviet experience, which was divided into 8 countries, should not occur in our country. The potential for division in our country may be relatively higher compared to the Soviets. Our country which consists of a group of islands, diverse cultures, so if we do not know each other then the potential of being separated into several groups of countries will be higher. The phone number needs to be how we deal with this, so this opinion leader is of course elite, academic, activist, and media. This should not only feel that this problem is mild because of the fate of 10 years, 25 years or 50 years later we will continue to Indonesia as it is now [3].

Towards 100 Indonesian independence in 2045, by conducting a simple study, the author conducted a test of knowledge for the younger generation. We want to know the level of literacy of Indonesia's territorial area in the younger generation. Intentionally chosen by the younger generation is Geography education students, because the assumption was built that Geography students should know more about Indonesia's territorial territory. National identity and defined territory are two important components in establishing a sense of nationalism. The myths of a particular nation emerge from the association between these two components, and its maps serve as a tool for expressing this association [4]

Related to the use of maps to detect object literacy about the phenomenon of the archipelago "1) Related to the use of maps to detect object literacy about the phenomenon of the archipelago. In the military, the use of maps is a matter of course. 2) Using maps in the classroom invites curiosity, encourages exploration and inspires problem solving. Maps can be used to explore a multitude of topics and can incorporate visual learning, spatial thinking and quantitative skills into a lesson.

\section{METHOD}

This paper is compiled based on the results of case studies when teaching Cartography for new students of class 2012. Students of Geography Education Faculty of Social Sciences, Surabaya State University.

To collect data, 50 randomly selected students were selected, including 30 female students and 20 students. The 50 students were given written tests by filling in a blind map showing the phenomenon of the unitary territory of the Republic of Indonesia.

Finally, after the data is collected, the data analysis is descriptive quantitative. Reasons for using maps. Because maps have several functions including: 1). Indicates the position or relative location of a place from another place, 2 ). show size in terms of distance and direction, 3 ). shows the shape of the surface elements of the earth presented, and 3 ). collect certain elements of the earth's surface in a form of affirmation. Thus the function of the map as a test tool about the territory of the unitary state of Indonesia can be used.

\section{Results AND DisCUSSION}

\section{A. The level of knowledge of the territory of the Unitary State of the republic of Indonesia}

On the use of test scores 1 to 10 , it is known that in the 50 students the average score of knowledge is 3,83, with a standard deviation of 0.26 . Thus, it is known that the level of knowledge/literate of students about the territory of the Unitary Republic of Indonesia is very low. In detail the results of the tests on the level of knowledge of the territory of the Unitary State of the Republic of Indonesia can be seen in the following table 1 
Table 1 Test Result for the Literate Level of the Territory of the Republic of Indonesia

$\begin{array}{llll}\text { No } & \begin{array}{l}\text { Regional Fenomena } \\ \text { Rank of True Answer }\end{array} & \text { Correct } & \text { Answer } \\ 1 & \text { Sea and ocean } 98,0 & 1 & \\ 2 & \text { Island name } \quad 32,06 & 2 & \\ 3 & \text { City name } \quad 20,60 & 3 & \\ 4 & \text { Boundaries of countries } & 20,50 \quad 4 \\ 5 & \begin{array}{l}\text { Name of montain 17,54 } \\ \text { average 37,74 }\end{array} & 5 \\ \text { Source: Result of Primary Data Processing }\end{array}$

Based on the table above, it can be seen the level of knowledge of the respondents, that 1) the name of the sea and the ocean is the highest score, thus the name of the sea in the Territory of Indonesia is best known to the respondent. Then to the lower level respectively, rank 2) is the name of the island, then rank 3 is the name of the city, and the number 4 is boundaries of countries, and finally is not widely recognized as the name of mountains \& mountains.

\section{B. Discussion about Literacy of the Unitary State of Republic of Indonesia}

Since the enactment of government decentralization, it has an impact on education policy. [5] education curriculum at the SMP / MTs level which put Geography as a platform for integrating IPS is expected to provide a fresh way to recognize the unified territory of the Republic of Indonesia, both in sociological, historical and economic dimensions

.By carrying out the National Examination on the Geography Lesson at the High School/Madrasah Aliyah level, the results of testing on new students in the Geography Education Department have not shown an encouraging footprint, especially the recognition of the Unitary State of the Republic of Indonesia which should have been pursued in high school / MA education.

If we refer to USAID's opinion, it is stated that the results of education do not have a positive impact on the quality of education. Explicitly stated " To the extent decentralization reduces the power of central education ministries, centrallyrun information systems that feed education policy decisions may collapse[6]. Furthermore, specifically [7] states that "the geographical facts affect the implementation of sector policies significantly. Therefore it is needed to put the relation between the spatial planning and the energy also into real time and space.

$\mathrm{He}$ knew the score of the sea and sea area really provide. The highest score is not yet known the cause. Because if calculated as a whole, that the respondent's knowledge or literacy level is also relatively low. The average literacy rate of the Nusantara region is $37.0 \%$, meaning that only $37.0 \%$ of research objects recognize the phenomenon of the archipelago of our country. That is, $63, \%$ of respondents were unable to answer or did not recognize the territorial territory of the archipelago. This condition, once again is very ironic, if it is traced that they have been introduced to the archipelago region from elementary, secondary, high school to university level.

The low test results with the assumption that the territory of the country itself is unknown, it is feared that if the territory of the country is controlled by another country, then our young generation will not know it. Thus, if the territory of the State does not know, it can be assumed that the taste of the ideals of the homeland of our generation has decreased [8].

As one of the results of research directly related to the unitary territory of the Republic of Indonesia is the point about state borders. In table 1 it is stated that the students who knew the national borders were $20.50 \%$, while the students who did not know the national borders were $80 \%$. This means that $80 \%$ of respondents do not really know the state boundary. If this condition is analogous to the condition of British youth as stated by the Teacher, then based on this research data the conditions of Indonesian youth's patriotism are also very low.

If the condition of the country's borders is unknown, then if one day the territory of his country is ruled by another country then the young man does not know. Thus, based on research data it is known that the patriotism condition of Indonesian youth is also low. This assumption is built on the argument that if the younger generation does not know the territory of their country, then where might they love their territory.

\section{CONCLUSIONS AND SUGGESTIONS}

Based on the description that has been submitted, it can be concluded that

1. The level of knowledge of Indonesia's young generation avoit its territory is very low

2. The low test result with the assumption that the territory of the country it self is unknown

3. The low level of knowledge about the territory of the Unitary State of the republic of Indonesia (especially the younger generation) is a warming to improve the formation of the young generation through various aspects

\section{REFERENCES}

[1] J. Budi, Pendidikan Kewarganegaraan Untuk Perguruan Tinggi. Jakarta: PT. Rajagrafindo Persada, 2014.

[2] Sapriya, Konsep Dasar Pendidikan Kewarganegaraan. Bandung: Laboratorium PKn UPI, 2017.

[3] F. Ismail, "Manajemen Berbasis Sekolah: Solusi Peningkatan Kualitas Pendidikan," J. Pendidik. Islam Iqra', 2018.

[4] B. R. Joyce, M. Weil, and E. Calhoun, Models of Teaching, 5th Edition. 1996

[5] C. K. S. Donald Ary, Lucy Cheser Jacobs, Asghar Razavieh, Introduction to Research in Education Eighth Edition. 2009.

[6] Michael, "Dasar-dasar Utama Praktek Belajar Kewarganegaraan,” Jakarta, 2012.

[7] A. Yahya and R. Machfiroh, Civic Education di Perguruan Tinggi Indonesia. Bandung: Alfabeta, 2014.

[8] Kokom Komalasari, Pembelajaran Kontekstual, Konsep dan Aplikasi. 2013.

[9] A. Supriati and M. Umar, "Optimization of the Civic Education as the Effort to Strengthen National Character in Multicultural Community," vol. 251, no. Acec, pp. 193-196, 2018. 